\title{
THE INFLUENCE OF SELECT BANKING SECTOR INDICATORS ON THE ECONOMIC GROWTH OF THE EUROZONE COUNTRIES
}

\author{
[Vliv vybraných ukazatelů bankovního sektoru na ekonomický růst zemí \\ Eurozóny] \\ Liběna Černohorská ${ }^{1}$, Vojtěch Kula ${ }^{2}$ \\ ${ }^{1}$ Univerzita Pardubice, Fakulta ekonomicko-správní, Studentská 95,532 10 Pardubice \\ Email:libena.cernohorska@upce.cz \\ ${ }^{2}$ Univerzita Pardubice, Fakulta ekonomicko-správni, Studentská 95,532 10 Pardubice \\ Email: kulavojtech@seznam.cz.
}

\begin{abstract}
This paper states its objective to be specifying the relationship between select banking sector indicators and the eurozone's economic growth. The indicators that were selected are analyzed using the Engle-Granger cointegration test, which is meant to confirm the long-term influence of the indicators of bank loans provided to the private non-financial sector and the M3 aggregate on the growth of GDP. Data from the years 1999-2016 are included in the analysis. On the basis of the tests that were conducted, it was determined that there is no cointegration relationship between any of the time series at a level of significance of 0.05 ; this means that a long-term relationship was not found between the amount of bank loans provided to the private non-financial sector and GDP or between the M3 monetary aggregate and GDP. The conclusions resulting from the analyses that were conducted are supported by graphic depictions of the data, which clarify the rejection of the hypothesis.
\end{abstract}

Keywords: bank, banking sector, cointegration test, economic growth, Eurozone, GDP.

JEL classification: E51, E47, C32

Doručeno redakci: 9.11.2016; Recenzováno: 18.11.2016; 28.11.2016; Schváleno k publikování: 1.3.2017

\section{Úvod}

Zvýšený zájem o vliv bankovních úvěrů na vývoj ekonomik je patrný především v posledních letech z důvodu celosvětové finanční krize. Příčinou této krize byla situace v USA způsobena neschopností různých ekonomických subjektů, především domácností, splácet nadměrné množství poskytnutých úvěrů. Proto se různí autoři začali věnovat vlivu velikosti poskytovaných úvěrů na vývoji HDP (napřr. Leitão, Armeanu et al., Ermişoğlu et al.).

Vymezení peněžních (měnových) agregátů, jejich struktura a dynamika vývoje poskytuje cenné informace nezbytné k realizaci měnových politik. Centrální banky proto sledují vazby mezi peněžními agregáty a inflací, peněžními agregáty a úrokovými sazbami a peněžními agregáty a HDP (Polouček 2009). S peněžními agregáty pracují centrální banky a zároveň je definují. Pomocí těchto agregátů ovlivňují množství peněz v národních ekonomikách. Jednotlivé centrální banky mohou definovat peněžní agregáty různě a v čase se mohou měnit. Peněžní agregáty představují peněžní prostředky, které se liší stupněm likvidity. Peněžní agregáty jsou zpravidla značeny velkým písmenem $\mathrm{M}$ a číslicí 1 až 5 . Čím nižší číslice, tím je vyšší likvidita peněžního agregátu. Peněžní agregát vyššího stupně v sobě zahrnuje celý předešlý peněžní agregát a navíc další aktivum, které je méně likvidní. Evropská centrální banka (ECB) definuje peněžní agregát „úzký“ (M1), "střední" (M2) a „široký‘“ (M3). Tyto agregáty se liší podle své likvidity. Úzké peníze M1 jsou tvořeny nejlikvidnějšími aktivy, tj. zahrnují oběživo (bankovky a mince) a také zůstatky, které lze okamžitě převést na oběživo nebo použít k bezhotovostní platbě (např. jednodenní vklady). Střední peníze M2 zahrnují 
úzké peníze (M1) a navíc vklady se splatností do dvou let a vklady s výpovědní lhůtou do tří měsíců. Definice M2 odráží zájem o analýzu a sledování peněžního agregátu, který kromě oběživa zahrnuje i likvidní vklady. Široké peníze M3 zahrnují M2 a obchodovatelné nástroje emitované sektorem měnových finančních institucí. Do tohoto agregátu patří některé nástroje peněžního trhu, zejména akcie či podílové listy fondů peněžního trhu a repo operace (European Central Bank 2009).

Cílem př́spěvku je nalezení vztahu (kointegrace) mezi vybranými ukazateli bankovního sektoru a ekonomickým vývojem zemí Eurozóny. U časových řad je totiž účelné rozlišovat tzv. krátkodobé vztahy (,short-run relationships“) a dlouhodobé vztahy („long-run relationships"'). První typ vztahů existuje pouze v relativně krátkém období, kdy tyto vazby postupem času mizí. Druhý typ vztahů má dlouhodobější trvání, které s postupujícím časem nemizí. Pokud odklon směrů vývoje časových řad je pouze krátkodobý (časem se vytrácí), tak existuje mez, za kterou odchylka nemůže jít - pak lze konstatovat, že časové řady jsou v rovnováze. Statistické vyjádření tohoto stavu se nazývá „kointegrace časových řad“. Jestliže zde tato mez není, potom nelze říci, že jsou v ekvilibriu, tedy ze statistického hlediska takové časové řady za kointegrované označit nelze. Je přirozené, že při zkoumání vztahů mezi ekonomickými časovými řadami jsou středem zájmu zejména řady kointegrované, nebot' pouze u nich lze analyzovat charakter jejich závislosti. Jestliže časové řady nejsou kointegrované, tedy dlouhodobě neobsahují žádný společný element, lze jejich zkoumání jako systému považovat za bezpředmětné, nebot' se dlouhodobě vyvíjejí nezávisle na sobě (Arlt 1997).

Mezi vybrané ukazatele bankovního sektoru jsou zvolena časová řada bankovních úvěrů poskytnutých soukromému nefinančnímu sektoru a časová řada peněžního agregát M3. Případná kointegrace těchto ekonomický veličin byla prokazována ve vztahu s vývojem HDP za využití Engle - Grangerova kointegračního testu. Tyto testy jsou aplikovány na vybraná statistická data od prvního čtvrtletí 1999 až do čtvrtého čtvrtletí 2016. Vstupní data jsou kvartálního charakteru a byla očištěna o sezónní vlivy. Hledaný vztah makroekonomických veličin lze tedy definovat na základě výstupu tohoto testu.

\section{Teoretická východiska}

Problematice působení bankovního sektoru na ekonomický vývoj jednotlivých zemí, se věnuje velké množství autorů v rámci svých mezinárodních výzkumných prací. Finanční zprostředkovatelé (bankovní instituce) mohou díky nižším nákladům v oblasti shromažd’ování a zpracování informací docílit kvalitnější alokace zdrojů (Boyd and Prescott 1996). Výsledky další studie Cetorelli a Gambera (2001) dokazují, že bankovní sektor usnadňuje př́ístup k úvěrům „mladým“ firmám a tím podporuje tempo hospodářského růstu, nebot' investice nových firem jsou $\mathrm{s}$ vyšší pravděpodobností vkládány do inovativních technologií. Bencivenga a Smith (1993) dochází k závěru, že bankovní sektor může díky sníženým monitorovacím nákladům snížit i nadměrné omezování úvěrů a tím zajistit zrychlený hospodářský růst země. Levine (2005) prokázal na základě empirického výzkumu propojení mezi fungováním finančního systému a hospodářského růstu.

Takats a Upper (2013) sledují vliv bankovních úvěrů na hospodářský růst v období po finanční krizi. Do analýzy zahrnuli data z 39 finančních krizí, kterým předcházely úvěrové boomy. Během těchto krizí vývoj bankovních úvěrů (at' už v reálných hodnotách, nebo $\mathrm{v}$ poměru k HDP) nekorelují s hospodářským růstem během několika let po oživení ekonomik. 
Již v minulosti byly analyzovány modely zaměřené na vztah peněžních agregátů a HDP. Na začátku 80. let minulého století americká centrální banka Fed spoléhala na peněžní agregát M1 při odhadech vývoje HDP a inflace. Avšak později se Fed přiklonil ve svých analýzách na širší měnové agregáty M2 a M3 při predikci HDP a inflace. Ovšem od 90. let byly i tyto agregáty méně spolehlivé, což souviselo s deregulací finančního systému v USA. Použité VAR modely dobře odhadovaly vztah peněžních agregátů a HDP, ovšem již tak dobře nedokázaly předpovědět inflaci (Jílek 2013).

Studie Feldsteina a Stocka (1994) zkoumá možnost využití peněžního agregátu M2 při ovlivnění nominálního HDP v USA. Jednoduchý model VAR optimalizace snižuje průměrnou standardní desetiletou odchylku ročního růstu HDP o více než 20 procent. Tyto statistické testy ukazují, že regulace růstu peněžního agregátu M2 může mít za následek významné snížení volatility růstu HDP. Autor Liang (2011) analyzuje vztah mezi nabídkou peněz (reprezentovaného peněžním agregátem M2) a ekonomickým růstem (HDP) v USA. Dochází k závěru, že časové zpoždění změny HDP je vyvolané změnou M2 a pomocí simultánních rovnic je možné predikovat budoucí změnu HDP podle odpovídající změny M2.

Mezi jedny z prvních autorů, jejichž výsledky nepotvrdily pozitivní vztah mezi peněžní zásobou ve vztahu k reálnému HDP, patř́ např́klad Fisher a Seater (1993). Tito autoři použili nové ekonometrické metody a došli k závěru, že pozitivní vztah sledovaných veličin v př́padě USA selhává. Postupem času vznikaly studie, které prováděly analýzy pro několik zemí současně, čímž se snažily zobecnit výsledky a potvrdit tak vztah množství peněz v ekonomice a HDP. Mezi prvními potvrdil pozitivní vztah Weber (1994), který provedl analýzu pro země G7, přičemž použival různé definice měnových agregátů pro testování robustnosti výsledků. Závěry v souladu s Weberem (1994) poskytují také McCandless a Weber (1995), kteří ovšem nenacházejí statisticky významný vztah mezi mírou růstu peněžní zásoby a reálným produktem a to ani pro jednu ze tř́ uvažovaných definic peněz u 110 zemí. Pozitivní vztah nacházejí pouze pro část 21 zemí patřících do OECD.

Na základě těchto výzkumů lze tedy konstatovat, že pro ekonomický růst jednotlivých zemí (vývoje HDP) se z oblasti bankovního sektoru jeví jako významný indikátor objem poskytnutých úvěrů. Na základě výzkumu autorů Levine (1999) a Beck et al. (2000), či Levine et al. (2000) je možné dále konstatovat, že lépe vysvětlují ekonomický růst pouze úvěry poskytnuté soukromému sektoru. Na základě rešerše odborné literatury se poté jevil jako vhodný vztah veličiny M3 (tzv. hlavního ukazatele objemu peněz v ekonomice) a HDP. Tento vztah byl již také dř́íve analyzován např́iklad autory Weber (1994) či King a Levine (1993). Tito dva autoři potvrdili, že pomocí tohoto ukazatele je možné vysvětlit ekonomický růst více než 80 zemí.

\section{Použité metody}

Vzhledem ke stanovenému cíli příspěvku je využito ke zkoumání vlivu vybraných ukazatelů úvěrů poskytnutých bankami soukromému nefinančnímu sektoru/HDP a M3/HDP v zemích Eurozóny konceptu kointegrace, kterým se zabývali zejména autoři Engle a Granger (1987), či z českých autorů např. Arlt (1997).

Ve snaze o aktuálnost výstupů jsou jednotlivé testy aplikovány na data z let 1999 až 2016 disponující kvartálním a sezónně očistěným charakterem. Data jsou čerpána ze statistik The Research Division of the Federal Reserve Bank of St. Louis (údaje o hrubém domácím produktu ve stálých cenách), z DataMarket.com (údaje o peněžním agregátu M3) a z Bank for 
International Settlements (údaje o výši bankovních úvěrů poskytnutých soukromému nefinančnímu sektoru).

Nejdříve je provedeno testování uvedených časových řad na optimální řád zpoždění. Vzhledem k nízkému počtu pozorování $(\mathrm{n}<60)$ je toto uskutečněno vždy pomocí Akaikeho informačního kritéria (dále jen AIC), kdy za nejlepší řád zpoždění (aplikovaný poté v následujících testech) se považuje vždy nejnižší hodnota AIC (Liew 2004). Testy jsou provedeny na základě vztahu veličin v rovnici (1). Blíže o této problematice je možné nalézt v Arlt a Arltová (2007).

$$
A I C(M)=\ln \sigma a 2+2 M / T
$$

M ......... počet parametrů

$\ln \sigma a 2 \ldots$ reziduální rozptyl

T ........ počet pozorování

Dalším krokem $\mathrm{v}$ analýze je ověření existence jednotkového kořene $\mathrm{v}$ časových řadách (neměnnosti náhodných veličin $\mathrm{v}$ čase), tedy zjištění, zda se jedná o stacionární či nestacionární časové řady. Rozlišení typů časových řad na stacionární a nestacionární je velmi důležité při zkoumání jejich vztahů, nebot' při použití nestacionárních časových řad může vzniknout situace, která se označuje jako zdánlivá resp. nesmyslná regrese.

Existuje několik statistických testů pro zjištění řádu integrace označovaných jako testy jednotkových kořenů. Zde je využit patrně nejpoužívanější z nich, který se podle svých autorů nazývá Dickey-Fullerův test (dále jen ADF test). Tento test tedy analyzuje, zda časová řada je typu I(0) - stacionární či $\mathrm{I}(1)$ - nestacionární. Analýza je provedena $\mathrm{v}$ programu pro ekonometrické analýzy Gretl 1.9.4. Více o této problematice je možné nalézt v Dickey a Fuller (1979).

K ověření hypotéz se v ADF testu obecně se využívají tři druhy testů - s konstantou, bez konstanty, a s konstantou a trendem. Při testování bylo vycházeno z předpokladu, že níže uvedený proces (2), kde testujeme, že $\varnothing=0$ (proměnná obsahuje jednotkový kořen), má tvar (Arlt, Arltová 2007):

$$
\Delta \mathrm{Xt}=(\varnothing 1-1) \mathrm{Xt}-1+\sum_{\mathrm{i}=1}^{\mathrm{p}} \alpha \mathrm{iXt}-1+e_{t}
$$

Xt .....závislá proměná

p ....... zpoždění,

$\mathrm{e}_{\mathrm{t}}$........reziduální složka.

Rozhodnutí o stacionaritě, respektive nestacionaritě časových řad bude provedeno na základě vyhodnocení p hodnoty (hladina významnosti vždy určena jako 0,05 ), která tedy s $95 \%$ pravděpodobností stanoví, zda došlo k zamítnutí nebo nezamítnutí nulové hypotézy. Ta byla pro tento test stanovena takto:

$\mathrm{H}_{0}$ : testované řady jsou nestacionární (existence jednotkového kořene)

$\mathrm{H}_{1}$ : testované řady jsou stacionární (neexistence jednotkového kořene)

Jelikož lze předpokládat nestacionaritu analyzovaných řad a zmíněná zdánlivá regrese nemůže vzniknout při použití stacionárních časových řad (řad typu $\mathrm{I}(0)$ ), nabízela se zde 
možnost odstranit ji diferencováním (stacionarizací) jednotlivých analyzovaných řad. Nicméně výzkumy provedené např́iklad Banerjee a kol. (1993) však dokázaly, že touto cestou nelze postupovat, nebot' při ní dochází ke ztrátě důležité informace o dlouhodobých vlastnostech vztahu mezi časovými řadami. Pro analýzu vztahů nestacionárních řad byl tedy využit tzv. EG test (Engle and Granger 1987), který je schopen analyzovat kointegraci nestacionárních časových řad dle níže uvedených hypotéz:

$\mathrm{H}_{0}$ : testované řady nejsou kointegrované

$\mathrm{H}_{1}$ : testované řady jsou kointegrované

Rozhodnutí o vztahu časových řad vychází z p hodnoty definované EG testem. V př́padě nezamítnutí nulové hypotézy $(\mathrm{p}>0,05)$ budou časové řady označeny nekointegrované - tedy za řady, mezi nimiž neexistuje dlouhodobý vztah, respektive za řady, které neobsahují žádný společný element a jejich zkoumání jako systému je bezpředmětné, nebot' se dlouhodobě vyvíjejí nezávisle na sobě. $V$ opačném prŕípadě $(p<0,05)$ budou časové řady označeny za kointegrované, tedy za řady, mezi nimiž na hladině významnosti lze prokázat dlouhodobý vztah.

\section{Vliv vybraných ukazatelů bankovního sektoru na ekonomický růst zemí v Eurozóně}

Pomocí Engle - Grangerového kointegračního testu je otestován vztah celkové výše úvěrů poskytnutých bankami soukromému nefinančnímu sektoru k HDP a peněžní agregát M3 k HDP. Obě veličiny jsou testovány jak v absolutních hodnotách (HDPEUR, BCEUR, MERU) tak v meziročních změnách (ZHDPEUR, ZBCEUR, ZMEUR). Použité časové řady jsou uvedeny od prvního čtvrtletí roku 1999 až do čtvrtého čtvrtletí roku 2016. Absolutní hodnoty HDP očištěné o sezónní vlivy jsou uvedeny ve stálých cenách bud' k roku 2009, nebo 2010.

\subsection{Test na optimální řád zpoždění pomocí Akaikeho kritéria}

Před použitím EG testu je nezbytné otestovat časové řady na optimální řád zpoždění, přičemž za závislou proměnou se považuje veličina HDP, respektive ZHDP. Tabulka 1 a Tabulka 2 uvádí hodnoty AIC kritéria na 4 řády zpoždění (nejnižší hodnota je vždy zvýrazněna tučně). Z výsledku optimálního zpoždění je zjištěno, že při absolutních hodnotách závislé proměnné HDP se jako optimální jeví dle nejnižších hodnot Akaikeho kritéria vždy zpoždění druhého řádu. Pro meziroční změny uvedených veličin poté zpoždění taktéž druhého řádu. Dále lze konstatovat, že u absolutních hodnot je nejnižšího AIC dosaženo v zemích Eurozóny při zahrnutí testu s konstantou. V př́ípadě meziročních změn je nejnižších hodnot AIC dosaženo shodně také při zahrnutí konstanty.

Tabulka 1: Výsledky optimálního zpoždění Eurozóny pro bankovní úvěry

\begin{tabular}{|c|c|c|}
\hline Rád zpoždění & AIC pro HDPEUR & AIC pro ZHDPEUR \\
\hline- & Test s konstantou & Test s konstantou \\
\hline 1 & 49,814157 & 2,585955 \\
\hline 2 & $\mathbf{4 9 , 5 3 3 4 7 6}$ & $\mathbf{1 , 8 9 7 6 4 5}$ \\
\hline 3 & 49,565212 & 1,923843 \\
\hline 4 & 49,579725 & 1,949215 \\
\hline
\end{tabular}

Zdroj: vlastní zpracování na základě výsledků programu Gretl 1.9.4. 
Tabulka 2: Výsledky optimálního zpoždění Eurozóny pro M3

\begin{tabular}{|c|c|c|}
\hline Ř́d zpoždění & AIC pro HDPEUR & AIC pro ZHDPEUR \\
\hline- & Test s konstantou & Test s konstantou \\
\hline 1 & 49,837520 & 2,508342 \\
\hline 2 & $\mathbf{4 9 , 5 0 1 0 7 2}$ & $\mathbf{1 , 9 1 8 9 8 3}$ \\
\hline 3 & 49,530967 & 1,947828 \\
\hline 4 & 49,530407 & 1,975706 \\
\hline
\end{tabular}

Zdroj: vlastní zpracování na základě uvedených dat zpracovaných programem Gretl 1.9.4.

\subsection{Ověření stacionarity časových řad}

Př́ípadná nestacionarita dat může vést ke zdánlivé regresi, jejíž úskalí spočívá zejména ve faktu, že aplikací metody nejmenších čtverců by bylo možné získat statisticky významné odhady parametrů regresní funkce, ačkoliv analyzované časové řady spolu nesouvisí. Z tohoto důvodu je potřeba otestovat použité časové řady pomocí Dickey - Fullerova testu. Výsledky ADF testu jednotkového kořene, $v$ tomto př́padě v modelu s konstantou, jsou v tabulce 4 a 5 . Jak je možné pozorovat, všechny časové řady s absolutními hodnotami byly na hladině významnosti 0,05 označeny za nestacionární (Tabulka 3, Tabulka 4). Časové řady ZBCEUR a ZMEUR taktéž, nicméně ZHDPEUR signalizuje na hladině významnosti 0,05 stacionaritu. $\mathrm{Z}$ tohoto důvodu budou v dalších analýzách vyloučeny páry obsahující tuto časovou řadu.

Tabulka 3: Výsledky testu ADF pro celkové úvěry poskytnuté bankami

\begin{tabular}{|c|c|c|c|}
\hline Zkratka proměnné & Hodnota p parametru & $\begin{array}{c}\text { Vyhodnocení výsledku ADF } \\
\text { testu }\end{array}$ & Ho: \\
\hline HDPEUR & 0,5711 & časová řada nestacionární & nezamítáme \\
\hline BCEUR & 0,5047 & časová řada nestacionární & nezamítáme \\
\hline ZHDPEUR & 0,0002623 & časová řada stacionární & zamítáme \\
\hline ZBCEUR & 0,5817 & časová řada nestacionární & nezamítáme \\
\hline
\end{tabular}

Zdroj: vlastní zpracování na základě výsledků programu Gretl 1.9.4.

Tabulka 4: Výsledky testu ADF pro M3

\begin{tabular}{|c|c|c|c|}
\hline Zkratka proměnné & Hodnota p parametru & $\begin{array}{c}\text { Vyhodnocení výsledku ADF } \\
\text { testu }\end{array}$ & Ho: \\
\hline HDPEUR & 0,5711 & časová řada je nestacionární & nezamítáme \\
\hline MEUR & 0,7048 & časová řada je nestacionární & nezamítáme \\
\hline ZHDPEUR & 0,0002623 & časová řada je stacionární & zamítáme \\
\hline ZMEUR & 0,5111 & časová řada je nestacionární & nezamítáme \\
\hline
\end{tabular}

Zdroj: vlastní zpracování na základě výsledků programu Gretl 1.9.4.

\subsection{Kointegrační analýza}

Aby bylo možné přistoupit $\mathrm{k}$ testování kointegrace časových řad pomocí Engle-Grangerova testu, je potřeba tedy vyřadit řady, které nesplňují základní předpoklady - tedy existenci jednotkového kořene, respektive nestacionaritu původních časových řad. Vzhledem k předchozím výsledkům Dickey - Fullerova testu je vyřazena časová řada ZHDPEUR.

Výsledky kointegrační analýzy pro zbylé časové řady jsou uvedeny v Tabulce 5 . Hodnota $p$ parametru označila časové řady za nekointegrované. 
Tabulka 5: Výsledky Engel - Grangerova kointegračního testu a ADF testu pro bankovní úvěry a M3

\begin{tabular}{|c|c|c|c|c|}
\hline Zkratka proměnné & P hodnota & Délka zpoždění & $\mathbf{H}_{0}:$ & Závěr \\
\hline HDPEUR-BCEUR & 0,5057 & 2 & nezamítáme & nekointegrace \\
\hline ZHDPEUR-ZBCEUR & \multicolumn{2}{|c|}{ nesplnění základních požadavků pro provedení kointegrace } \\
\hline HDPEUR-MEUR & 0,1284 & 2 & nezamítáme & nekointegrace \\
\hline $\begin{array}{l}\text { ZHDPEUR-ZMEUR } \\
\text { Zdroj: vlastní zpracování na základě uvedených dat zpracovaných programem Gretl 1.9.4. }\end{array}$ \\
\hline
\end{tabular}

Je možné konstatovat, že ve sledovaném období nebyl prokázán vzájemný dlouhodobý vztah těchto veličin. Závěry vyplývající z provedených analýz jsou podloženy i grafickou vizualizací dat, ze které je patrné zamítnutí hypotézy (Obrázek 1, Obrázek 2).

\subsection{Ověření zjištěných výsledků pomocí vizualizace dat}

Závěry vyplývající z verifikace stanové hypotézy je možné podložit i grafickou vizualizací dat, ze kterého je patrné zamítnutí hypotézy. Data vstupující do analýzy vykazují silný nárůst úvěrů poskytnutých bankami soukromému nefinančnímu sektoru i peněžního agregátu M3 (Obrázek 1 - pravá osa). Ačkoliv je zde patrný silný nárůst těchto sledovaných veličin, HDP takřka nereaguje (Obrázek 1 - levá osa). Po celosvětové finanční krizi byla nucena Evropská centrální banka (ECB) stanovit úrokové sazby velmi blízko nule, finanční systémy nebyly stabilizovány a ekonomická situace v zemích Eurozóny se začala prudce zhoršovat. Proto byla ECB nucena přistoupit $\mathrm{k}$ tzv. nekonvenční měnové politice a to $\mathrm{v}$ podobě kvantitativního uvolňování peněz za účelem monetární expanze (a tím i růstu peněžního agregátu $\mathrm{M} 3$ ). $\mathrm{K}$ růstu úvěrů ve sledovaném období přispěly nízké a později i záporné úrokové sazby na finančním trhu stanovené ECB (European central bank 2016).

Obrázek 1: Průběh HDPEUR, MEUR a BCEUR 1999-2016

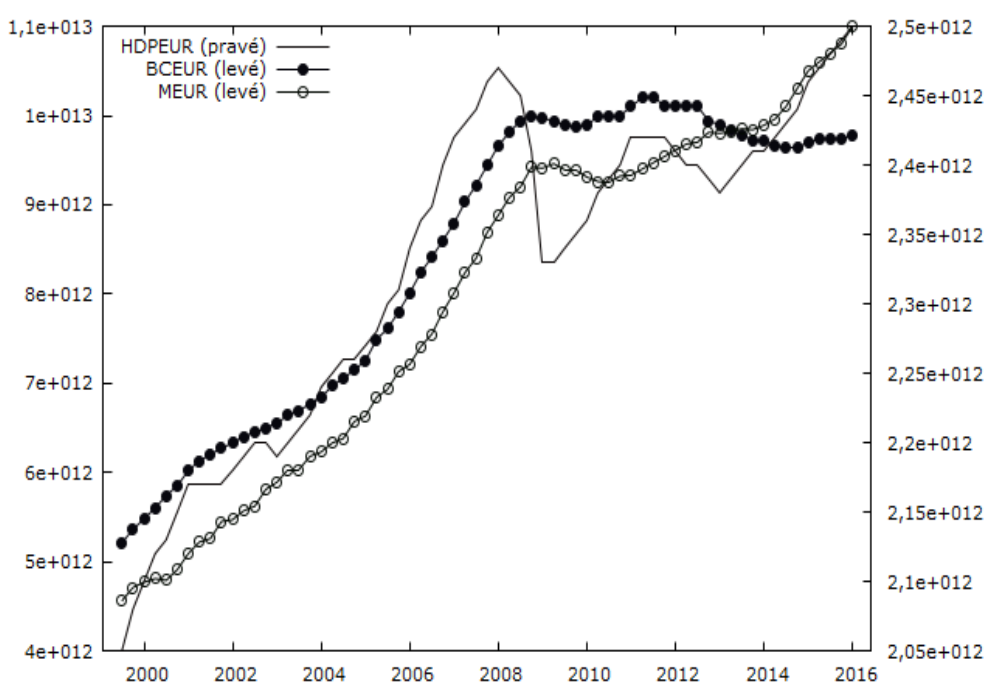

Zdroj: vlastní zpracování na základě uvedených dat zpracovaných programem Gretl 1.9.4. 
Obrázek 2: Průběh ZHDPEUR, ZMEUR a ZBCEUR 1999-2016

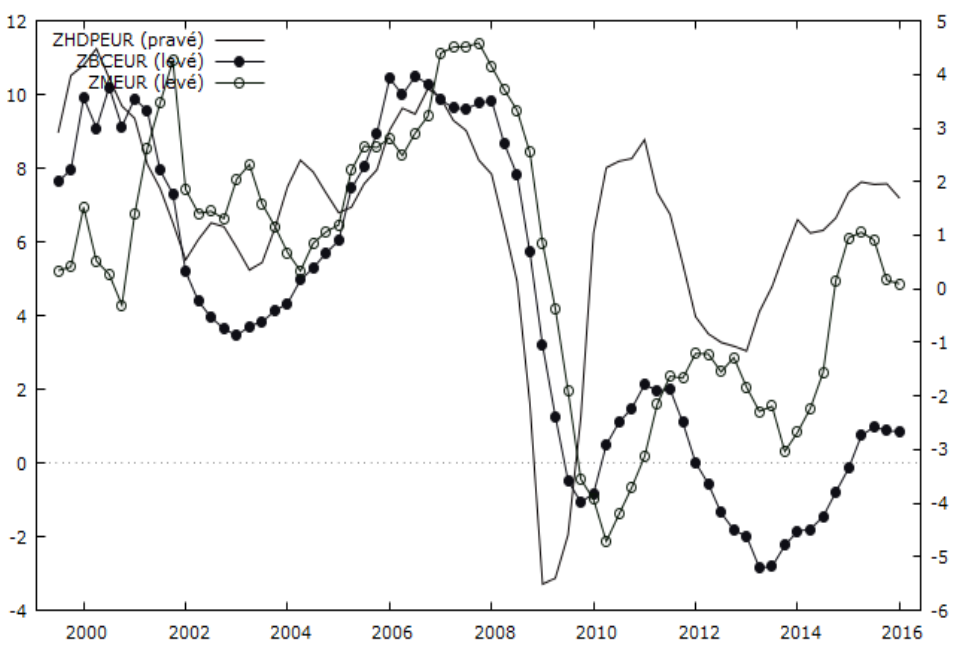

Zdroj: vlastní zpracování na základě uvedených dat zpracovaných programem Gretl 1.9.4.

\section{Závěr}

Z výsledků analýz vyplývá, že všechny testované časové řady jsou podle ADF testu nestacionární a bylo třeba upravit časové řady diferencováním. Na základě EngleGrangerového testu kointegrace lze uvést, že časové řady nejsou kointegrované a nebyla zde prokázána závislost vývoje HDP na základě vývoje peněžního agregátu M3 a bankovních úvěrů poskytnutých soukromému nefinančnímu sektoru. Zjištěné závěry jsou $\mathrm{v}$ souladu s ekonomickou teorií a závěry Fishera a Seatera (1993) či McCandlesse a Webera (1995). Výsledky nepotvrzují při aplikaci Engle-Grangerového testu kointegrace existenci statisticky významného vztahu mezi HDP a M3, resp. HDP a bankovních úvěrů poskytnutých soukromému nefinančnímu sektoru. Nenalezení dlouhodobého vztahu mezi výší bankovních úvěrů poskytnutých soukromému nefinančnímu sektoru a HDP koresponduje se závěry autorů Takats a Upper (2013), kteří došli k závěru, že vývoj bankovních úvěrů nemá vliv na hospodářský růst během několika let po oživení ekonomik.

V dalším výzkumu by bylo možné se zaměřit na modely, které připouštějí endogenitu proměnné. Takové studie již existují, ale převážně zpracovávají data z USA (např. Liang 2011 či Feldstein and Stock 1994). Bylo by jistě zajímavé aplikovat stejné modely na Eurozónu. Použití těchto metod ale vyžaduje větší množství pozorování a delší časové řady. To je v prrípadě Evropské unie problém, nebot' Eurozóna vznikla v roce 1999. I během této doby ale došlo k zásad ním změnám, kterým musela Eurozóna čelit. Ve sledovaném období proběhla celosvětová finanční krize a v reakci na ni musela Evropská centrální banka přistoupit $\mathrm{k}$ nekonvenční měnové politice. V rámci této měnové politiky došlo ke kvantitativnímu uvolňování peněz a stanovení záporných úrokových sazeb. Oba tyto faktory působily na M3 i na vývoj bankovní úvěry poskytnuté soukromému nefinančnímu sektoru.

\section{Poděkování}

Článek vznikl za finanční podpory Grantové agentury České republiky (projekt GAČR No. 17-02509S - Emerging financial risks during a global low interest rate environment) a Vědecko-výzkumné aktivity $\mathrm{v}$ oblasti "Ekonomický a sociální rozvoj v soukromém a veřejném sektoru“, č. SGS_2016_023. 


\section{Literatura}

[1] ARLT, J., 1997. Kointegrace v jednorovnicových modelech. Politická ekonomie, 45(5), 733-746. ISSN 0032-3233.

[2] ARLT, J. a M. ARLTOVÁ, 2007. Ekonomické časové řady: [vlastnosti, metody modelování, př́klady a aplikace]. Praha: Grada Publishing. ISBN 978-80-247-1319-9.

[3] BANERJEE, A. and P. NEWBOLD, 1993. Co-integration, error correction, and the econometric analysis of non-stationary data. Oxford University Press. ISBN 01-9828810-7.

[4] BANK FOR INTERNATIONAL SETTLEMENTS, 2016. Credit to the non-financial sector. [online]. [vid. 20. května 2016]. Dostupné z: http://www.bis.org/statistics/tot credit.htm

[5] BECK, T., R. LEVINE and N. LOAYZA, 2000. Finance and the Sources of Growth. Journal of Financial Economics, 58(1-2), 261-300. ISSN 0304-405x.

[6] BENCIVENGA,V. and B. SMITH, 1993. Some Consequences of Credit Rationing in an Endogenous Growth Model. Journal of Economic Dynamics and Control, 17(1-2), 97122. ISSN 0165-1889.

[7] BOYD, J. and E. PRESCOTT, 1986. Financial Intermediary-Coalitions. Journal of Economic Theory, 38(2), 211-232. ISSN 0022-0531.

[8] CETORELLI, N. and M. GAMBERA, 2001. Banking Market Structure, Financial Dependence and Growth: International Evidence from Industry. The Journal of Finance, 56(2), 617-648. ISSN 0022-1082.

[9] DATAMARKET. M3 for Euro Area, 2016. [online]. [vid. 9. prosince 2016]. Dostupné z: https://datamarket.com/data/set/1uya/m3-for-euro-area-quarterly-data\#!ds=1uya\&display $=$ line

[10] DICKEY, D. A. and W. A. FULLER, 1979. Distribution of the Estimators for Autoregressive Time Series with a Unit Root. Journal of the American Statistical Association, 74(366a), 427-431. ISSN 0162-1459.

[11] EUROPEAN CENTRAL BANK, 2009. The ECB's definition of euro area monetary aggregates. [online]. [cit. 2012-07-19]. Dostupné z: http://www.ecb.int/stats /money /aggregates/aggr/html/hist.en.html

[12] EUROPEAN CENTRAL BANK, 2016. ECB Annual Report 2015. [online]. [vid. 10. záŕí 2016]. Dostupné z: https://www.ecb.europa.eu/pub/pdf/annrep/ar2015en.pdf?776f8e3f5 ee4da49e0f8e7ad5316b547

[13] ENGLE, R. F. and C. W. J. GRANGER, 1987. Co-Integration and Error Correction: Representation, Estimation, and Testing. Econometrica, 55(2), 251-276. ISSN 0012-9682

[14] FELDSTEIN, M. and J. H. STOCK, 1994. The use of a monetary aggregate to target nominal GDP. Monetary policy. The University of Chicago Press. ISBN 0-226-50308-9.

[15] FISHER, M. E. and J. SEATER, 1993. Long-run Neutrality and Superneutrality in an ARIMA Framework. American Economic Review, 83(3), 402-415. ISSN 00028282.

[16] FRED ECONOMIC DATA, 2016. Real Gross Domestic Product for Euro area (19 countries). [online]. [vid. 20. května 2016]. Dostupné Z: https://fred. stlouisfed. org/series/CLVMNACSCAB1GQEA19 
[17] JÍLEK, J., 2013. Finance v globální ekonomice II. Měnová a kurzová politika. Praha: Grada Publishing. ISBN 978-80-247-4516-9.

[18] KING, R. G. and R. LEVINE, 1993. Finance and Growth: Schumpeter Might Be Right. The Quarterly Journal of Economics, 108(3), 717-737. ISSN 0033-5533.

[19] LEVINE, R., 1999. Law, Finance, and Economic Growth. Journal of Financial Intermediation, 8(1-2), 8-35. ISSN 1042-9573.

[20] LEVINE, R., 2005. Finance and Growth: Theory and Evidence. Handbook of Economic Growth, 1, 865-934. ISSN 0033-5533.

[21] LEVINE, R., N. LOAYZA and T. BECK, 2000. Financial Intermediation and Growth: Causality and Causes. Journal of Monetary Economics, 46(1), 31-77. ISSN 0304-3932.

[22] LIANG, F., 2011. The Relationship Between Money Supply and The GDP of United States. Diss. Hong Kong Baptist University Hong Kong. [online]. [vid. 2. prosince 2016]. Dostupné z: http://lib-sca.hkbu.edu.hk/trsimage/hp/08050597.pdf

[23] LIEW, V. K.-S., 2004. Which Lag Length Selection Criteria Should We Employ? Economics Bulletin, 3(33), 1-9. [online]. [vid. 21. června 2016]. Dostupné z: http://ssrn.com/abstract $=885505$.

[24] McCANDLESS, G. T. and W. E. WEBER, 1995. Some Monetary Facts. Federal Reserve Bank of Minneapolis Quarterly Review, 19(3), 2-11. ISSN 0271-5287

[25] POLOUČEK, S., 2009. Peníze, banky, finanční trhy. Praha: C.H. Beck, 2009. ISBN 97880-7400-152-9.

[26] TAKATS, E. and CH. UPPER, 2013. Credit and Growth after Financial Crises. BIS Working Paper No. 416. [online]. [vid. 15. prosince 2016]. Dostupné z: http://papers.ssrn.com /sol3/papers.cfm?abstract_id=2375674

[27] WEBER, A., 1994. Testing Long-Run Neutrality: Empirical Evidence for G7 Countries with Special Emphasis on Germany. Carnegie-Rochester Conference Series on Public Policy, 41, 67-117. doi: 10.1016/0167-2231(94)00014-X. 